\title{
RELATIONSHIP MARKETING IN CUSTOMER LOYALTY OF COMMERCIAL GALLERIES IN TIMES OF COVID-19
}

\author{
Luz CANO, Djanira CASTRO, Wagner VICENTE-RAMOS $\mathbb{D}^{*}$ \\ Faculty of Business Sciences, Universidad Continental, Huancayo, Peru \\ Received 26 February 2021; accepted 19 August 2021
}

\begin{abstract}
The main objective of the study is to determine the level of dependence between relationship marketing and the level of customer loyalty to the brand. The study was conducted through a quantitative approach using the CAWI method. Relationships were determined by several factors. The loyalty factors are: Differentiation, Personalization, Satisfaction, Loyalty, usually. The relationship marketing indicators are: Trust, Commitment, Customer Satisfaction, Intention to renew the relationship.

The survey results were processed using statistical methods. In particular, internal consistency checks performed on the questionnaire with questions to use Cronbach's alpha. The use of such criteria allows to draw conclusions about the high level of consistency. The coefficient of determination was used for statistical verification of dependence. The results of the calculations confirmed a high level of dependence. Dependence was also confirmed by calculating p-values with a high level of probability.

Conclusions were drawn according to the results of the empirical investigation.
\end{abstract}

Keywords: relationship marketing, customer loyalty, Covid-19, trust, commitment, customer satisfaction.

JEL Classification: M1, M3.

\section{Introduction}

Abtin and Pouramiri (2016) mentions that today many of the companies focus on marketing efficiency, when what they could do is to change the direction towards relationship marketing so that they can establish and effective customer relationship management. In today's competitive world, customers are the center of attention of companies and their main satisfaction is to obtain a competitive advantage and for this the main requirement is to achieve customer satisfaction, that is to exceed expectations and meet their needs; and this will serve to have the competitive advantage and therefore the differentiation with its competition. Likewise, Niño de Guzmán (2014) considers that in today's global economy what predominates are services and in a way that is increasing, companies consider that it is appropriate to raise strategies in relationship marketing to be focused in this context. Relationship marketing is one of the most essential tools for there to be adequate competition, because customer one to be identified individually that there is a specialized and personalized attention, the organization most be constantly communicating about any innovation or differentiating factor of your preferred brand, classically marketing has been very focused on the transactional, so that its sole and important purpose was to obtain customers and to build customer loyalty to make the sale and thus get to form a positive bond between the company and the customer. On the other hand, relationship marketing has been concerned with giving greater importance to obtaining, persuading and preserving customers with the sole purpose of building customer loyalty.

Loyalty programs are a powerful relationship marketing tool that is becoming popular to encourage customer loyalty and can introduce benefits to both customer and companies. Customers loyalty is an important factor in any organization; because gaining new customer is more expensive than keeping them, it is estimated that in 25\% of the retail sector lose their customers every year, but that a small group of loyal customers increased the company's profits by more than 25\%, Magatef and Tomalieh (2015).

For Leninkumar (2017), customer loyalty has been widely analyzed by several researchers as a central element of an organization during the last two decades, any company in any industry can move to a higher level of advantage by achieving customer loyalty in addiction to

${ }^{*}$ Corresponding author. E-mail: wvicente@continental.edu.pe 
satisfying their needs as these two terns always go hand in hand. Customer loyalty is considered a key business strategy and a major asset of every company that ensures the company's success and improves its profitability level. In today's fast-paced, ever-changing world, building and maintaining customer loyalty requires much more effort.

The main success factors of relationship marketing in customer loyalty are trust, commitment, satisfaction and relationship quality, being able to achieve a structured action plan that contains the management of deferred marketing, performance, loyalty, collaboration, interaction management with such a plan we can improve the relationship one to one with the customer, know their expectations, needs and preferences; this favoring and better relationship marketing Catagua et al. (2019). The correct use technology for interaction, communication between customers and company, is one of the important factors for obtaining a more effective relationship, because this will boost the interaction with the customer and purchasing needs, taking advantage as a point of measurement of benefits, which can be calculated in a certain period in order to evaluate the contributions of relationship marketing.

The contemporary business environment requires companies to make a change where they focus on relationship marketing is why the authors Aka et al. (2016) mention that for them involve building a satisfactory long-term relationship, which are based on customer acquisition transactions hence of maintaining a mutually beneficial relationship with existing customers. For Abtin and Pouramiri (2016), customer loyalty is achieved through the shopping experience that can be considered as the final phase in modern marketing, this customer loyalty can lead to behaviors such as loyalty and referral marketing, this is a key strategy and the greatest asset of the company that will represent its level of profitability. In today's fast paced world characterized by constant changes shows us very clearly that for the application of relationship marketing and customer loyalty many efforts are required, one of them is to be in constant training since most old commercial organizations did not take into account this tool and lost their customer; that is why the process of creating strong ties of loyalty with customers is called relationship marketing.

In a study by Fabeil et al. (2020), on the crisis of entrepreneurial firms, suggests that the experience of this crisis leads entrepreneurs to be more rational and guided by planned behavior on making decisions, entrepreneurs have been demonstrating their ability to innovate by putting in place survival mechanisms and thereby manage marketing through alternative promotions on pricing, distribution channel, product reengineering and even an online campaign. And so, as governments make decisions in response to the coronavirus, companies must adapt to he changing needs of their employees, customers and suppliers, while at the same time addressing financial and operational challenges. In all this context, managers, entrepreneurs and business owners face the urgency and complexity of restarting their business and at the same time a necessity for many companies to develop capabilities they should have invested in earlier, such as digitization, data, cloud, automated and agile operations and above all ecommerce, entrepreneurs must see the reopening of their business as the beginning of journey towards a broader transformation.

That is why we take into account in these times of crisis to relationship marketing and we have great references of the application of relatonship marketing for customer loyalty, one of them is Ikea, a furniture manufacturer with changing the font in its catalog managed to have loyal customers; Dell the computer store that made a special line for corporate customers to whom the ordering process is adapted according to their needs and finally American Airlines since it implemented the frequent flyer program achieved customer loyalty. According to Roig (2017), mentions that $75 \%$ of U.S. companies with loyalty plans obtain a positive and fast return on investment, it also mentions that companies invest in marketing to attract potential customers, new ones and achieve better customer service, to keep them. Faced with the global health emergency, the progressive economic recovery was carried out in stages according to the needs of the people, where most companies are betting more on an aggressive marketing strategy and appealing to the situation that has been living in this war to get new customers. However, today that we are living a confinement and paralyzed economy, the relationship marketing strategy is more important today than ever by the market, as these types of strategies are more profitable, does not require much investment, but to train oneself more, by the digital media where information abounds.

Referring to the shopping malls according to Peru Retail (2016), he mentions that with the increase of shopping centers, the malls have begun to react to the advance of these and their competition, although it is not yet generalized throughout the system but in those that are very close to modern channels, In addiction, the purchase option for the consumer is becoming larger not only in variety of brands but also in what many value the price and although today, with the increase of promotions in shopping malls, they can be found with different prices, there are places where the customer can achieve even more discounts with the old technique of bargaining, with this technique and others, relationship marketing will be achieved. Also, according to the newspaper Navarro (2020), it mentions that the growth plants of the commercial galleries remain firm throughout this year despite the slowdown of Peruvian economy, in addiction, it is excepted to realize the opening of new stands in the highlands of Peru at the ends of this years in order for consumers to access new business platforms. With the activation of the economy, commercial galleries seek to reinvent themselves with new strategies to reach consumers, therefore they will seek to meet new customer expectations and needs by maintaining contact before, during and after the purchase in order to achieve customer loyalty. Fairlie (2020), mentions that after the closure of stores and business in Peru and around the world due to the coronavirus is unprecedent, stores, factories and many other businesses have closed due to policy 
mandates, downward demand changes, health concerns or other factors. Companies have just begun to incorporate technology into their business models, and are looking for support to create a Facebook page and manage communication via WhatsApp, as well as start offering their products sealed or bagged and with cash on delivery and various methods of virtual payment.

According to the newspaper El Comercio (2020), in the Junín region all commercial establishments are looking for ways to meet the requirements that customers have to obtain massive visit and is reflect in sales, despite the efforts is an uncertainty of commercial galleries know if their customers are loyal. Due to the sanity emergency that our country is going through, the capacity of the galleries has been reduced, the number of people per mouth entering the main commercial galleries of the city of Huancayo - Peru is approximately 2000 people, being the weekends the most visited days by people, on the other hand it should be noted that not all the stands are operating, in an unstructured observation we realized that there is a great variety of products and prices, the vendors have a good deal with customers. In addition, the security personnel look for ways to stock up for the other hand, the customer service staff does not have the necessary knowledge to properly advise the buyer and have not implemented the post-purchase follow-up following the emergence of Covid-19, it should be noted that people due to the situation that exist in the country take into account the security and protocols to go shopping.

This sanitary crisis of the Covid-19 brought with it the reduction of the capacity to $40 \%$, in addition to consumers reduced their purchasing power due to the loss of jobs and reduction of their income, also the financial problems of some merchants to restart their operations such as the payment of rent of premises even though these were kept closed, the contract of personnel to make home delivery, greater demand from buyers to comply with sanitary standards and adapt to new digital trends so that their business remains in force. The commercial galleries, adopted the following strategies: know the demands and expectations of the customer, which was bases on what the customer would like to do for him in that way understand the problem that the customer wants to solve for it is important to take into account the economic possibilities of each client to know what you can offer according to what you can or are willing to pay, thus achieving create a relationship whit the customer and at the same time loyalty, in this way the commercial galleries will improve their work dynamics; however, it is necessary to measure the relationship marketing to know how it influences the loyalty of customers of the mentioned galleries and measure it through comprehensive questionnaires with key questions, thus strengthening the link witch customers.

The purpose of the investigation is to determine how relationship marketing influences customer loyalty in the main shopping malls in the city of Huancayo - Peru 2020.

\section{Literature review}

\subsection{Relationship marketing}

Over the years, public relations and relationship-oriented marketing became a major part of organizations operating in both the private and public sector, for Puma (2019), mentions that relationship marketing is the process of creating, developing and improving relationships with customers and other actors involved in the relationship, know as stakeholders, it is also considered as all marketing activities aimed at establishing developing and maintaining successful relationship exchanges so it is considered necessary to establish points of importance, develop appropriate techniques and strengthen the exchanges that are of vital importance in relationship marketing. Relationships with customers go beyond satisfying needs, it is essential to work hand in had with customer to achieve a closer approximation of their real expectation, to make the customer feel like the protagonist of the company.

Aka et al. (2016), characterize relationship marketing as a wide range of relationship variables that have developed over the past decades in products also as service markets and both consumer and business to business to business sectors, in addition to creating an exchange of value, not necessarily economic but to generate a winwin relationship in the medium or long term that benefits both parties, there is also a two-way communication and collaborative business to customer, one of the most outstanding features is advertising as it does not focus on the entire segment, but to the targets, all leading to customer satisfaction. Abtin and Pouramiri (2016), mention that to apply relationship marketing some methodologies such as digital marketing, inbound marketing and content marketing are needed, adding to this the tools to consider are the blog, social networks, email marketing, offline actions, among others. To apply relationship marketing everything starts with demographic and historical data of customers that would serve to understand who they are, what they buy and how to relate to them in the long term, the data also serve to track customer purchases. It is necessary to know the audience and create the ideal profiles for potential customers, thus creating unique marketing strategies for each target and that is where the most personalized tools are applied to satisfy the customer, for which results are obtained separately, that is to say for each tool used. Among the main dimensions we have:

Trust; it is the firmness, conviction and it could be said that the security that the consumer has in front of a product or service, who by his experience knows that the brand in which he has deposited his money, will not fail him and also knows that it will meet all his expectations; for a brand to reach that point is not easy, since it involves many aspects, especially the planning and monitoring of the relationship they have with customers (Laguna \& Rosendo, 2012). For the authors Bricci et al. (2016) trust allows lower transaction costs and promotes long-term relationships, it is a conduit of success between strategic 
alliances, they refer that trust has two levels, macro that examines an organizational and social level and micro level that examines the interpersonal and group relationships. Trust is seen as the willingness of individuals to increase their vulnerability to the actions of another whose behavior cannot be controlled.

Commitment; for authors Bricci et al. (2016), commitment in organizations is based on desires, instrumental commitment is that the customer must stay with the organization and normative commitment refers to an obligation to stay with the organization; with these three components, commitment can be defined as a force that compels an individual to buy from a supplier which can be affective, instrumental or normative. Commitment is an essential ingredient for long-term success, long-term relationships, trust and customer satisfaction are the main determinants of commitment. Commitment has been a fundamental part of any business relationship. It consists of the linkage and active participation that from the top management of an organization to the lowestranking employee are part of this process, it is considered primarily a behavioral approach on the one hand and an attitudinal approach on the other (Laguna \& Rosendo, 2012).

Customer satisfaction; it is considered as the feeling or attitude of the customer towards a product or service, it is essential for a company since therein lies the recommendation to other consumers, when the needs or expectations of the customer have been met the results of this satisfaction can be one of the keys to increased sales of an organization (Laguna \& Rosendo, 2012). According to Bricci et al. (2016), customer satisfaction is a factor that generates trust in the organization that offers the product or service, maintaining a relationship with the customer will increase the satisfaction and desire of the consumer and continue to keep a relationship with the company, satisfaction creates a positive impact on commitment and one of the main effects of trust is satisfaction.

Relationship renewal intention; according to Bricci et al. (2016), the intention to renew the relationship is important to maintain the relationship over time between companies and customers, in which the company will analyze the concentration of purchase and profitability generated by the customer, aiming to generate satisfaction with the customer since the cost of obtaining a new customer is much lower than that of retaining an existing customer. The measurement of purchase intent plays an important role in decision making in companies as it helps us to have an idea of future demand that could be achieved, thus determining how feasible it is to invest in the production of a new product. Another important aspect of measuring purchase intention is that it serves as a guide in the structure of new marketing strategies since it influences each of the factors of the marketing mix (Laguna \& Rosendo, 2012).

Gonzales et al. (2017), aims to determine the relationship between variables of study, in order to propose strategies aimed at improving business relationships and achieve attract more potential customers in this way it will be possible to identify the dimensions of greater influence on the level of relationship marketing. The results obtained from the research are that there is a high significant relationship on the customer portfolio variable, through the dimensions: purchased price, knowledge of the service, customer satisfaction, trust, intention to renew the relationship. The article contributes to the present research by its contributions regarding the dimensions of the relationship marketing variable, providing us with concepts and the influence they have on the variable in question. The research would have contributed more if there was a greater coincidence with the dimensions of the relationship marketing variable.

Molina et al. (2017). in the article or entitled "Relationship marketing to improve customer loyalty in savings and credit cooperatives in Latacunga Canton -", in the magazine Redipe vol. 6, aims to determine whether relationship marketing can improve customer loyalty in savings and credit cooperatives in Latacunga Canton, technically and scientifically substantiate the elements and strategies of relationship marketing that allow customer loyalty. The results obtained are that customers are not well loyalized with the company and this makes them not last in time, given that it is necessary to implement well-defined strategies, excellent customer service and trust in order to form a bond that is long term. Finally, the researcher concludes that, by conducting bibliographic research on Relationship Marketing and its functions, it can be said that the most important part is to build an interaction with the customer in this way to maintain a long-term relationship through strategies. The article contributes to maximize profitability and customer loyalty through different mechanisms, strategies and actions to achieve trust and value. The new paradigm is focused on customer loyalty through communication and personalized treatment, and in this way it will be possible to build long-term relationships with customers, they will be faithful and loyal to the brand, which will contribute to the success of any company.

\subsection{Customer loyalty}

Loyalty seeks to establish a long-term bond between the company, brand and customer so that the relationship is sustainable over time.

Leninkumar (2017), defined customer loyalty as the promise of buyers to purchase certain products, services and brands from an organization for a constant period of time, regardless of new products and innovations from competitors but loyal customers are not forced to leave; loyal customers recommend their buying experience to others and in that way we refer to people. The optimal flow of profits is the result of customer retention and loyalty will help the company to cover its costs, by increasing the purchase of the majority of the company's customers the profits will increase and the company will enjoy greater efficiency in providing services to consumers, therefore costs are reduced; and happy and loyal customer will attract more potential customers to the company. Likewise, for Magatef and Tomalieh (2015), customer loyalty is the 
attitude and behavior of the customer to prefer a brand from all competing brands, either because of product or service satisfaction or because some loyal customer encouraged him to consume the product or service offered; to obtain loyal customers requires loyalty programs that are structured marketing efforts that reward and therefore encourage normal buying behavior that is potentially beneficial to the company.

For the authors Bricci et al. (2016), it is characterized because it depends on teams, employees, suppliers and owners committed to building a lasting successful companies, in addition to reducing costs and increasing profitability which is the cost of recruiting a new customer is five times more than the cost of retaining an existing customer, customer loyalty is recognized as customer behavior that characterize it in terms of repurchase intentions, word of mouth and recommendation.

Loyalty seeks to establish a long- term bond between the company, brand, institution and customer so that the relationship is sustainable over time once the purchase is completed. For a customer to be loyal, it is necessary to know in depth what he/she feels. And for this purpose it is necessary to investigate his/her tastes, expectations and needs, and then process the information obtained and offer the customer those products that best suit his/her needs. In this way, we will obtain loyal customers who will recommend us through referral marketing, which will, be reflected in increased sales for the company (Alet, 2007).

The main loyalty strategy is to provide after- sales services focused on providing the customer, consumer after - sales services, such as returns and refunds, advise the customer on the care that the product, delivery service, free installation of the product, repair and maintenance of the product in this way provides product warranty (Vieites Rodriguez, 2012).

Differentiation; it is based on creating a distinctive element, the added value offered by the company that cannot be achieved in any other company, this refers to the characteristics of the products, presenting them in a unique way compared to those of the competition. Distinction, valuation, equity and proportionality are fundamental characteristics within this type of strategies that are most valued by the customer (Alet, 2007).

The differentiation strategy for Zehir et al. (2015), is related to being unique in the market with unique products and service or different from other companies, differentiation provides greater profitability, creating brand loyalty and sensitivity to low prices, due to this differentiation of products or services is that customers are willing to pay a higher price for a good or service. This strategy reduces price or services is that customers are willing to pay a higher price for a good or service. This strategy reduces price sensitivity, reduces the power of suppliers, creates a barrier to entry and reduces the threat of substitute products that is competitors cannot easily imitate our product or service because it is unique.

Customization; personalization is the set of strategies and actions that allow us to offer a range of differentiated products and service to the customer, personalization consists of generating systems of processes and procedures in sum of operations, to generate a relationship between company and customer, it is worth saying that personalization is the most valued by customers in this way we achieve that they feel identified with the company since each customer is different and requires characteristics that fit their needs and expectations (Alet, 2007).

Zehir et al. (2015), each customer is different and requires certain characteristics of a certain product, to be able to configure requires the help of the customer that is to say to have all the information required to perform the customization successfully we must recognize and identify the customer and with all this adapt the articles to their needs.

Satisfaction; without this element loyalty could not exist. All those characteristics and dimensions of the product that the customer perceives must meet his expectations and needs and a certain pleasure. It should be taken into account that the customer will be disappointed if the product does not meet his expectations, if the product is equal to the expectations he had the customer will be really fascinated (Alet, 2007).

Ismail and Yunan (2016), satisfaction is broadly defined as a difference between customers' expectations and experience performance after using a service or product in a certain time; many researchers refer to service quality, satisfaction and loyalty as different but closely related terms. Satisfaction according to various perspective is a decision made by customers based on the impact of the product or service on the customer where quality, the product itself and price are involved. Loyalty; this is the commitment on the part of the customer to the company and vice versa. This is an important step towards customer loyalty, since the customer will always prefer the company over others, and not only when the company offers discounts or benefits (Alet, 2007).

For Bricci et al. (2016), loyalty is based on a set of factors, trust, positive relationship and an emotional bond, therefore, the customer has a marked tendency regarding what they buy and who they buy, to know if the customer is a loyal a permanent condition is required is that the customer makes repeated purchases, buy different lines of products or services and recommends the products to other people.

Habitually; this element is essential for loyalty, it has a repetitive sense on the part of the customer towards the company, the habitually is composed of the frequency, volume, quantity, duration with our customers make their purchases (Alet, 2007).

Zehir et al. (2015), is the essential and indispensable component of loyalty that has a sense of repetition of transactions by a customer towards a company, the habitually is composed if elements that give information and delimit the nature we have frequency, which collects the approximate time between purchases of a customer; duration, which refers to the period of time in which a set of transactions elapses; seniority, which measures the 
time since a customer made the first purchase and when at least the second purchase was made; and finally repetition, which is the period of time since the date of the last purchase.

\subsection{Hypotheses}

The following hypotheses have been elaborated from the conceptual model shown in Figure 1 and Figure 2.

H1: Relationship marketing has a positive influence on customer loyalty in the main shopping malls of the city of Huancayo - Peru 2020.

H2: Trust positively influences customer loyalty in the main shopping malls of the city of Huancayo - Peru 2020.

H3: Engagement positively influences customer loyalty in the main shopping malls of the city of Huancayo - Peru 2020.

H4: Customer satisfaction positively influences customer loyalty in the main shopping malls of the city of Huancayo - Peru 2020.

H5: The intention to renew the relationship influences customer loyalty in the main shopping malls of the city of Huancayo - Peru 2020.

From which the following conceptual model and hypotheses are established.

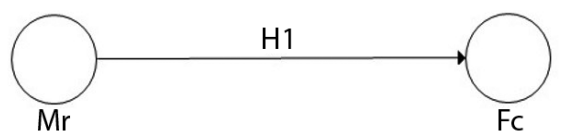

Figure 1. Conceptual model and general hypothesis

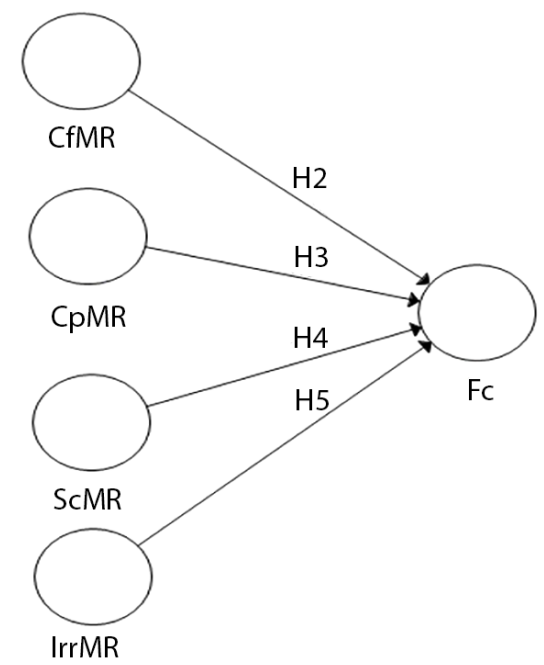

Figure 2. Conceptual model and specific hypotheses

\section{Research model}

For relationship marketing, the following indicators were considered for the dimensions:

Confidence (CfMR): Does the salesperson show willingness to solve your problems? (CfMR1), Does the salesperson inspire confidence in you? (CfMR2), Do you feel safe with the security inside the facilities? (CfMR3), Is there a commitment on the part of the salespeople to offer you good service? (CfMR4), Do the products you purchase come with a warranty? (CfMR5).

Commitment (CpMR): Does the salesperson have the ability to answer your questions about a product? (CpMR6), Do you consider the material of the products to be durable? (CfMR7), Does the salesperson have the materials and equipment to do his/ her job well? (CfMR8).

Customer satisfaction (ScMR): Are you satisfied with the service provided by the salespeople? (ScMR9), Are you satisfied (a) with the product designs? (ScMR10), Are you satisfied (a) with the variety of products? (ScMR11), Do you consider that this mall id different from others? (ScMR12), Did you service offered exceed your expectations? (ScMR13).

Intention to renew the relationship (IrrMR): Do you frequently purchase your products in this shopping mall? (IrrMR14), Would you make purchase at this mall again? (IrrMR15)

The following indicators were considered for the customer loyalty variable:

Differentiation (DFC): Are you recognized for the good service you offer? (DFC16), Do you offer any added value in your products? (DFC17), Do you feel that the attention you receive is the same for all customers? (DFC18), Do the prices of the products match the quality of the products? (DFC19).

Personalization (PF), Do you prefer to shop at this mall because of the good treatment you receive? (PF20), Did you have a good shopping experience? (PF21), Was your online shopping experience satisfactory? (PF22), Do you consider that the security protocols are adequate (PF23).

Satisfaction (SFC): Are you satisfied with the quality of the products? (SFC24), Are you satisfied with the promotions? (SFC25), Do you consider the payment systems to be reliable? (SFC26), Do you consider that the delivery service is reliable? (SFC27).

Loyalty (FdFC): Do you shop at this mall because it sells products of recognized brands? (FdFC28), Do you prefer to shop at this mall rather than at the competition? (FdFC 29).

Habitually (HFC): Do you purchase more than one product? (HFC30), Do the products you purchase indicate the date of shipment and expiration date? (HFC31).

\section{Methodology}

A study was conducted with a quantitative approach, applied type, correlational - causal level and deductive inductive method; with the purpose of testing the effect of the dimensions of the relationship marketing variable influences on customer loyalty (Hernández et al., 2014).

\subsection{Population and sample}

The study population consisted of customers served in the last three months (May, June and July) of this year in the 
main shopping malls of the city of Huancayo- Peru, 7250 people. The sample size was 365 clients with a margin of error of 5\%, a "p" factor of 0.5 and "q" of 0.5 and a confidence level of $95 \%$.

\subsection{Data collection instrument}

The study population consisted of 7250 customers of both shopping malls. The sample size (365 customers of the shopping malls) was obtained with a margin of error of $5 \%$, a "p" factor of 0.5 and "q" of 0.5 , confidence level of $95 \%$. A targeted questionnaire was developed based on 15 questions for the relationship marketing variable ( 5 on trust, 3 on commitment, 5 on customer satisfaction, 2 on intention to renew the relationship) and 16 questions on customer loyalty (4 on differentiation, 4 on personalization, 4 on satisfaction, 2 on loyalty, 2 on habitually). The Delphi methodology was used for the validation of the by applying the survey to 365 customer of the commercial galleries that participated simultaneously with the pilot. For the substantive and formal validation, the verification of the closed questions on a Likert scale (1 totally disagree, 4 totally agree) was considered.

\subsection{Data analysis procedure}

Data collection was carried out through the use of Google Forms. For this process, we contacted the managers of the commercial galleries, who provided us with a data base of the salespersons; a first call was made so that the conversation could be direct, in order to explain the objective of the study and in this way they could provide us with the database of their customer. The survey was sent to commercial gallery customers on a virtual basis. For the development of the que questionnaire, no problems were detected on the part of the respondents, since they were willing to do so.

\section{Results}

\subsection{Evaluation of the measurement model}

Table 1 and Table 2 shows the measurement analysis of the model, based on the reliability and validity of the measurement scales. Regarding reliability, the internal consistency of the scales is evidenced by the Cronbach Alpha value (Between 0.830 to 0.972 ) and the composite reliability (between 0.909 to 0.975 ). With respect to convergent validity, all factor loadings are at or above 0.806 and all scales have average variance extracted (AVE) percentages greater than $50 \%$. The discriminant validity of the construct was approved by the Formell Larcker criteria, which verifies the independence of each of the scales, considering that the square root of the AVE is greater than the correlations with the rest scales. In all cases, the assumption was met.

As shown in Figure 3 in all cases an R2 greater than 0.862 was obtained and in Figure 4 in all cases an R2 greater than 0.869 was obtained, which shows that it is highly significant, also showing that the model significantly
Table 1. Results of the model measurement analysis of the variables

\begin{tabular}{|l|c|c|}
\hline \multicolumn{1}{|c|}{ Variables } & $\mathrm{Mr}$ & $\mathrm{Fc}$ \\
\hline Cronbach alpha & 0.969 & 0.972 \\
\hline Composite reliability & 0.972 & 0.975 \\
\hline Factor loads (range) & $0.807-0.807$ & $0.819-0.862$ \\
\hline Average variance extracted (AVE) & 0.700 & 0.706 \\
\hline Discriminant Validity & 0.36 & 0.840 \\
\hline
\end{tabular}

Table 2. Results of the model measurement analysis of the dimensions

\begin{tabular}{|l|c|c|c|c|}
\hline \multicolumn{1}{|c|}{ Dimensions } & Cf & Cp & Irr & Sdc \\
\hline Cronbach alpha & 0.850 & 0.910 & 0.830 & 0.910 \\
\hline Composite reliability & 0.909 & 0.933 & 0.921 & 0.939 \\
\hline Factor loads (range) & $\begin{array}{c}0.866- \\
0.893\end{array}$ & $\begin{array}{c}0.851- \\
0.888\end{array}$ & $\begin{array}{c}0.925- \\
0.927\end{array}$ & $\begin{array}{c}0.855- \\
0.878\end{array}$ \\
\hline $\begin{array}{l}\text { Average variance } \\
\text { extracted (AVE) }\end{array}$ & 0.770 & 0.735 & 0.857 & 0.754 \\
\hline Discriminant Validity & 0.877 & 0.857 & 0.926 & 0.868 \\
\hline
\end{tabular}

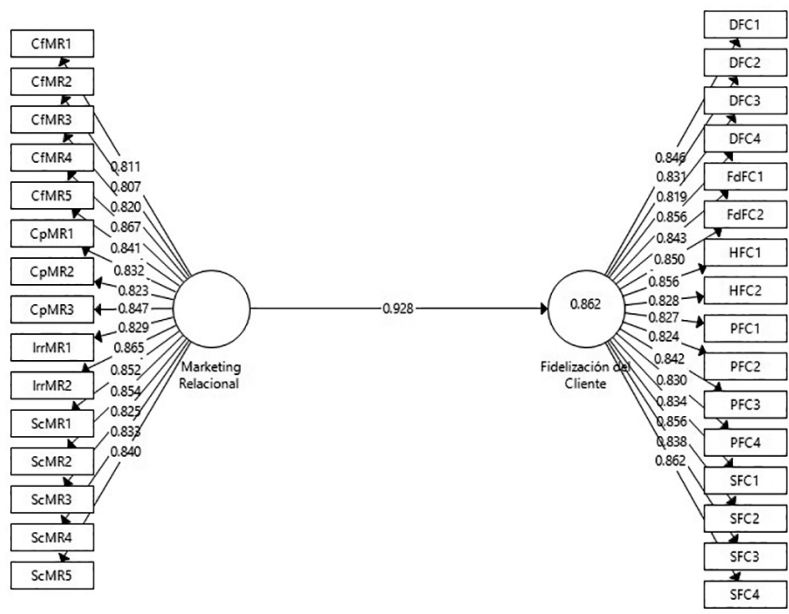

Figure 3. Relationship marketing and customer loyalty modeling

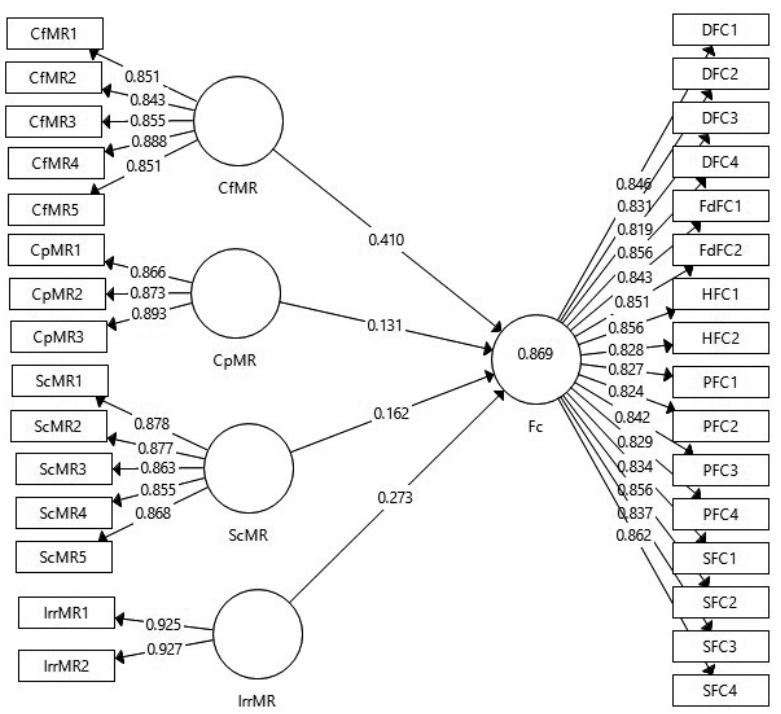

Figure 4. Hypothesized model with structural equations 
explains the variance of the conceptual constructs of the dependent variable.

Table 3. Results of the model structure analysis

\begin{tabular}{|l|c|c|c|c|}
\hline \multicolumn{1}{|c|}{$\begin{array}{c}\text { Specific } \\
\text { Hypothesis }\end{array}$} & Cf - Fc & Cp - Fc & Irr - Fc & Sdc - Fc \\
\hline Sample average & 0.133 & 0.410 & 0.273 & 0.162 \\
\hline $\begin{array}{l}\text { Standard } \\
\text { deviation }\end{array}$ & 0.051 & 0.057 & 0.040 & 0.063 \\
\hline Statisticians & 2.554 & 7.147 & 6.847 & 2.562 \\
\hline P Values & 0.011 & 0.000 & 0.000 & 0.010 \\
\hline Decision & $\begin{array}{c}\text { Accept } \\
\text { H2 }\end{array}$ & $\begin{array}{c}\text { Accept } \\
\text { H3 }\end{array}$ & $\begin{array}{c}\text { Accept } \\
\text { H4 }\end{array}$ & $\begin{array}{c}\text { Accept } \\
\text { H5 }\end{array}$ \\
\hline
\end{tabular}

\subsection{Evaluation of the structural model}

After verifying the validity and reliability of the measurement model, the relationships of the constructs were tested. Hypotheses were tested by examining the road coefficients and their significance levels. Considering that 4 specific relationships and the general one have $\mathrm{p}<0.05$ (if $\mathrm{p}$ value is lees than 0.005 , the null hypothesis is rejected), the proposed hypotheses $\mathrm{H} 1, \mathrm{H} 2, \mathrm{H} 3, \mathrm{H} 4$ and $\mathrm{H} 5$ are accepted as shown in Table 3 and Table 4.

Table 4. Results of the model structure analysis

\begin{tabular}{|l|c|}
\hline \multicolumn{1}{|c|}{ General Hypothesis } & MR- FC \\
\hline Sample average & 0.928 \\
\hline Standard deviation & 0.014 \\
\hline Statisticians & 67.102 \\
\hline P Values & 0.000 \\
\hline Decision & Accept H1 \\
\hline
\end{tabular}

\section{Discussion}

\subsection{Regarding the influence of relationship marketing on customer loyalty}

Relationship marketing generates a positive impact on customer loyalty $(\mathrm{p}<0.05)$ of the main shopping malls in the city of Huancayo - Peru, Vieites Rodriguez (2012) states that the various tools used as the after sales service, reward system, customization with the customer and added value in customers that aims to interact, create an experience and better meet the needs, in this way are directly related to customer loyalty. Thus training the company to be adaptable to changes and able to face different circumstances, since relationship marketing is constantly evolving and always gives the necessary tools to the company to continue operating in a changing landscape like the one we are in. The aforementioned strategies are the ones that the galleries chose to carry out since they considered that in this way they would achieve customer loyalty and ended up being successful since it was obtained as a result that relationship marketing positively influences customer loyalty.

\subsection{Regarding the reliance of relationship marketing on customer loyalty}

Trust has a positive impact on customer loyalty $(\mathrm{p}<0.05)$ in the main shopping malls of the city of Huancayo Peru, according to Laguna and Rosendo (2012) trust is central, bidirectional element of relationship marketing in order to generate long - tern ties with customers and is associated with the reputation that the merchants of the shipping malls seek to maintain. Customers are satisfied with the confidence that sellers give them regarding the predisposition of the confidence, the perspective of risk, predisposition and security with both the product and the establishment, thus showing that they are directly related to customer loyalty. Therefore, more strategies should be added to improve the relationship of trust with customers, for example by providing more quality products, transmitting security in contact with the customer and credibility, for this it is necessary to have communication skills, conduct training to staff and even provide a protocol of care and image to works in order to strengthen the confidence in customers.

\subsection{Regarding relationship marketing's commitment to customer loyalty}

The commitment generates a positive impact on customer loyalty $(\mathrm{p}<0.05)$ of the main shopping malls in the city of Huancayo - Peru, which indicates Laguna and Rosendo (2012) the commitment establishes an emotional bond with buyers, it is a factor of utmost importance for relationship marketing. The costumer points out that the sellers are in the capacity to absolve doubts, have the materials and equipment for the collaborators to carry out their work, showing that it is necessary to improve in the training of the workers in front of the products or services they commercialize, besides innovating in the products and adapting to change to satisfy in a better way the needs and demands of the customer. This shows that the merchants have invested time and resources in the relationship with the customer and have obtained their loyalty.

\subsection{Regarding relationship marketing customer satisfaction in customer loyalty}

Customer satisfaction has a positive impact on customer loyalty $(\mathrm{p}<0.05)$ of the main shopping malls in the city of Huancayo - Peru 2020, for Laguna and Rosendo (2012) we are facing a new breed of customers, which evaluates their totality contact with the organization that are also known as moments of truth, these customers are concerned about the way the sllers react, the way they pack and delivery the products, in addition to advertising and the speed of response to complaints, treatment and response of workers at the time if serving them. The tools that the commercial galleries used and if they obtained results were the attention, the desing and variety of the products, differentiation of the galleries, exceeding expections, thus showing that are directly related to customer 
loyalty. It should be considered that the attention of the salespersons is the feedback that the customer continuously provide them; it is a very valuable tool for the improvement if satisfaction.

\subsection{Regarding the intention to renew the relationship of relationship marketing in customer loyalty}

The intention to renew the relationship generates a positive impact on customer loyalty $(\mathrm{p}<0.05)$ of the main commercial galleries of the city of Huancayo - Peru, which indicates, Vieites Rodriguez (2012) the customer is carried away by the susceptibility for the renewal of the purchase relationship, for this we must devote more resources and efforts to those who are already customers because they are the most loyal with the purchase, is that to have new customers we need to implement a whole marketing strategy that includes recruitment campaigns, generation of trust in the brand, promotions, the probability of return, the amount of products or services purchased and the frequency of purchase are important factors to obtain customer loyalty, showing that are directly related to customer loyalty, so we must show more interest in these customers since they are the most frequent buyers, then we should increase a solid strategy of customization of offers. The commercial galleries carried out loyalty programs that they offered to their recurring customers, considering this a good option to incentivize purchases; they also set key dates in their calendar to carry out campaigns and promotions, and finally, exclusive access was another of their tools for their recurring customers.

\section{Conclusions}

García-Madurga et al. (2021), highlight that companies have been forced to privatize their business models to ensure their continuity after the pandemic, since digital marketing and sales channels in companies, teleworking and the consumption of technological products such as artificial intelligence, have led to the adoption of innovations related to the value proposition and the generalization of collaborative initiatives among all actors in the business ecosystem.

Relationship marketing generates a positive impact on customer loyalty in the shopping malls Centro Comercial Constitución and Astoria Plaza de Huancayo, it has been determined that there is a positive influence of 0.000 between relationship marketing and customer loyalty, these results are due to the fact that both shopping malls have stated according to the questionnaire that trust, commitment, customer satisfaction, the intention to renew the relationship will allow customers or consumers to feel that there is a bond that unites them with the malls and that they are loyal because of the strategies that were used.

In relation to the first specific hypothesis, it is stated that there is a strong relationship between trust and customer loyalty of the shopping malls Centro Comercial Constitución and Astoria Plaza de Huancayo, according to the result obtained in Table 3 and Table 4 , the p-value is 0.011 , that is to say that there is a positive influence between trust and customer loyalty. Showing the results, a new investigation can be carried out with respect to this dimension, which is trust, reviewing the indicators, investigating in the matrices to learn more about this dimension and perhaps there is a probability of adding other indicators to help strengthen the dimension, in this way the customer's trust can be recovered, which in the future will lead to customer loyalty.

In relation to the second specific hypothesis, it is affirmed that there is a strong relationship between commitment and customer loyalty of the shopping malls Centro Comercial Constitución and Astoria Plaza de Huancayo, according to the result obtained in Table 3 and Table 4, the $\mathrm{p}$ value is 0.000 , that is to say that there is a positive influence between commitment and customer loyalty. Demonstrating the result the relationship that exists is very significant, it has been working with the brand through cultural advertising huancaína, managing to attract the customer with a feeling, in this way the commitment will be more certain in the commercial galleries.

Regarding the third specific hypothesis, it is stated that there is a strong relationship between customer satisfaction and customer loyalty of the shopping malls Centro Comercial Constitución and Astoria Plaza de Huancayo, according to the result obtained in Table 3 and Table 4, the $\mathrm{p}$ value is 0.000 , that is to say that there is a positive influence between customer satisfaction and customer loyalty, therefore the proposed hypothesis three is accepted, a very close communication between customers and shopping malls was worked.

Regarding the fourth specific hypothesis, it is stated that there is a strong relationship between the intention to renew the relationship and customer loyalty of the shopping malls Centro Comercial Constitución and Astoria Plaza de Huancayo, according to the result obtained in Table 3 and Table 4 , the p-value is 0.010 , that is, there is a positive influence between the intention to renew the relationship and customer loyalty; therefore, the fourth hypothesis is accepted.

\section{Acknowledgements}

The authors are grateful for the support of the representatives and the administrative area of the main commercial galleries of the city of Huancayo, for providing us with the data used at the time of conducting the questionnaires on Relationship Marketing in customer loyalty of Huancayo galleries, Peru 2020.

\section{Author contributions}

1. Luz Cano, was responsible for data collection and the design and development of the findings.

2. Djanira Castro, was in charge of analyzing the results and interpreting the data.

3. Wagner Vicente-Ramos, wrote the first draft of the article. 


\section{Disclosure statement}

The authors do not have any conflict of interest.

\section{References}

Abtin, A., \& Pouramiri, M. (2016). The impact of relationship marketing on customer loyalty enhancement (Case study: Kerman Iran insurance company). Marketing and Branding Research, 3, 41-49. https://doi.org/10.33844/mbr.2016.60203

Aka, D., Kehinde, O., \& Ogunnaike, O. (2016). Relationship marketing and customer satisfaction: A conceptual perspective. Binus Business Review, 7(2), 185-190. https://doi.org/10.21512/bbr.v7i2.1502

Alet, J. (2007). Marketing directo e interactivo: campañas efectivas con sus Clientes (2 ed.). Esic Editorial.

Bricci, L., Fragata, A., \& Antunes, J. (2016). The effects of trust, commitment and satisfaction on customer loyalty in the distribution sector. Journal of Economics, Business and Management, 4(2), 173-177. https://doi.org/10.7763/JOEBM.2016.V4.386

Catagua, K., Choca, I., \& Freire, F. (2019). Marketing relacional para fidelizar a los clientes de Baratodo S.A. en la ciudad de Guayaquil. Revista Observatorio de la Economía Latinoamericana, 3(1), 20-39. https://www.eumed.net/rev/oel/2019/01/ marketing-relacional-baratodosa.html

El comercio. (2020). Gobierno reduce aforo en centros comerciales a 40\% para evitar aglomeraciones. https://elcomercio.pe/economia/peru/gobierno-reduce-aforo-en-centros-comercialesa-40-para-evitar-aglomeraciones-nndc-noticia/?ref=ecr

Fabeil, N. F., Pazim, K. H., \& Langgat, J. (2020). The impact of Covid-19 pandemic crisis on micro-enterprises: Entrepreneurs' perspective on business continuity and recovery strategy. Journal of Economics and Business, 3(2), 9. https://doi.org/10.31014/aior.1992.03.02.241

Fairlie, R. (2020). The impact of COVID-19 on small business owners: Evidence from the first three months after widespread social-distancing restrictions. Journal of Economics \& Management Strategy, 29(4), 727-740. https://doi.org/10.3386/w27462

García-Madurga, M.-A., Grilló-Méndez, A. J., Morte-Nadal, T. (2021). La adaptación de las empresas a la realidad COVID: una revisión sistemática. Retos Revista de Ciencias de la Administración y Economía, 11(21), 55-70. https://doi.org/10.17163/ret.n21.2021.04

Gonzales, J., Heredia, F., \& Lozada, V. (2017). Marketing relacional y ampliacion de la cartera de clientes en la empresa $\mathrm{s}$ \& h ingenieros S.R.L - Chiclayo. Horizonte Empresarial, 4(1), $1-16$.
Hernández, R., Fernández, C., \& Baptista, P. (2014). Metodología de la Investigación (6 ed.). Mc Graw Hill.

Ismail, A., \& Yunan, Y. M. (2016). Service quality as a predictor of customer satisfaction and customer loyalty. LogForum, 12(4), 269-283. https://doi.org/10.17270/J.LOG.2016.4.7

Laguna, P., \& Rosendo, V. (2012) Marketing relaciional (1 ed.). Dykinson.

Leninkumar, V. (2017). The relationship between customer satisfaction and customer trust on customer loyalty. International Journal of Academic Research in Business and Social Sciences, 7(4), 450-465. https://doi.org/10.6007/IJARBSS/v7-i4/2821

Magatef, S. G., \& Tomalieh, E. F. (2015). The impact of customer loyalty programs on customer retention. International Journal of Business and Social Science, 6(8), 78-93.

Markova, M., Modliński, A., \& Moreira Pinto, L. (2020). Creative or analitical way for career development? Relationship marketing in the field of international business education. Creativity Studies, 13(1), 99-113. https://doi.org/10.3846/cs.2020.6625

Molina, J., Salazar, P., \& Guaigua, J. (2017). El marketing relacional para mejorar la fidelización de los clientes en las cooperativas de ahorro y crédito del cantón Latacunga - Ecuador. Boletín Redipe, 6(5), 177-195.

Navarro, M. (2020). Gestión El diario de Economía y Negocios. La guía completa para mantener vigente tu negocio en medio de la crisis. https://gestion.pe/economia/empresas/protocolossanitarios-contra-covid-19-cuales-son-los-principales-desafios-para-las-empresas-noticia/

Niño de Guzmán, J. C. M. (2014). Estrategia de marketing relacional para lograr la fidelización de los clientes. Apuntes Universitarios, 4(2), 25-42.

https://www.redalyc.org/articulo.oa?id=467646129002

Perú Retail. (2016). Las galerías comerciales se mantienen en el gusto del público peruano. https://www.peru-retail.com/galerias-comerciales-mantienen-gusto-publico-peruano/

Puma, P. (2019). Marketing Relacional y Calidad de Servicio Educativo. Visión Centrada en la Universidad Andina Néstor Cáceres Velásquez 2017, 4(1), 31-39.

Roig, J. (2017). Programas de lealtad: el centro es el cliente Recuperado 9 de febrero de 2021. https://mba.americaeconomia. com/articulos/reportajes/programas-de-lealtad-el-centro-esel-cliente

Vieites Rodriguez, R. (2012). Atraer y fidelizar clientes. (1 ed.). C.E.E.I GALICIA, S.A.

Zehir, C., Can, E., \& Karaboga, T. (2015). Linking entrepreneurial orientation to firm performance: the role of differentiation strategy and innovation performance. Procedia-Social and Behavioral Sciences, 210, 358-367. https://doi.org/10.1016/j.sbspro.2015.11.381 